\title{
AnAlyses of Bio-Energy Properties From Malaysian Local Plants: Sentang and SESENDOK
}

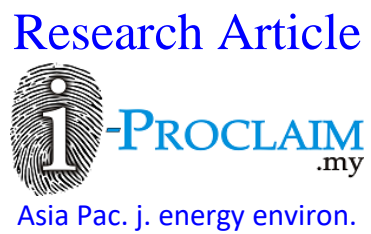

Asia Pac. j. energy environ.

\section{Nazia Hossain ${ }^{1,2}$, Rafidah Jalil ${ }^{2}$}

${ }^{1}$ Department of Biotechnology-Biochemical Engineering, Faculty of Engineering, International Islamic University Malaysia (IIUM), Gombak, MALAYSIA

${ }^{2}$ Forest Research Institute Malaysia, Kepong, 52109 Selangor, MALAYSIA

*Email for Correspondence: bristy808.nh@gmail.com

Abstract

Various types of plants with several energy analysis methods have been experimented to produce bio-energy. In this study, two Malaysian local plants Sentang (Azadirachta excelsa) and Sesendok (Endospermum malaccense) have been used to determine their capability of bio-energy production. Our study focused on the analyses of bio-energy properties by using proximate analysis method separating moisture content $(\%)$, volatile matter $(\%)$, ash content $(\%)$, fixed carbon (\%) and calorific value $(\mathrm{MJ} / \mathrm{kg}$ ) from Sentang and Sesendok. Proximate analyses of these plants proved lengthy flammability, very high amount of ignition, heat generation, net energy and negligible pollution effect. The calorific values for Sentang and Sesendok are $16.84 \mathrm{MJ} / \mathrm{kg}$ and $16.95 \mathrm{MJ} / \mathrm{kg}$ respectively. As Malaysia is tropical country mapping a large area of land with an evergreen plantation, so both trees Sentang and Sesendok species would be the efficient sources of bio-energy production.

Key words

Sentang; Sesendok; Bio-energy; Proximate Analysis; Calorific Value

1/9/2018 Source of Support: FRIM | No Conflict of Interest: Declared

This article is is licensed under a Creative Commons Attribution-NonCommercial 4.0 International License.

Attribution-NonCommercial (CC BY-NC) license lets others remix, tweak, and build upon work non-commercially, and although the new works must also

acknowledge \& be non-commercial.

\section{INTRODUCTION}

Bio-energy, a renewable energy obtained from organic matter such as plants, household wastage, human wastage, animal manure etc. Nowadays the carbon in bio-fuels is extracted from atmospheric carbon dioxide by growing plants; the combustion of a bio-fuel does not result in a net increase of carbon dioxide in the Earth's atmosphere. The multiple uses of Biomass can enhance energy sustainability and support to establish Green Technology (Abdullah, 2005). From few decades ago, the upgraded usage of biomass has increased largely in many areas in the world. In the light of the Kyoto GHG reduction targets, many countries are motivated to higher biomass utilization. Besides, recently rocketed oil price increased the level of interest in bio-energy production. On average, in industrialized countries biomass contributes quite less amount of bio-energy supplies but on the other hand developing countries biomass contributes almost 20-30\% supply of the total energy demand on average (Potential Contribution of Bioenergy to the World's Future Energy, 2007).

Azadirachta excelsa (Sentang) belongs to the Meliaceae family. It is native to Borneo (Sabah, Sarawak and Kalimantan), Sulawesi, Papua New Guinea and the Philipines (Mindoro and Palawan). In Malaysia, it is known as kayu bawang or ranggu. Old sentang is light-weight to medium-weight hardwood and colors brownish or grayish buff in old trees what we used for our sample in these experiments. Sentang wood is a familiar source of traditional wood fuel; it dries very fast and very burnable. That is why Sentang is expected as a good source of energy properties (Mustapa, Wahab, \& Choon, 2009).

Endospermum malaccense (Sesendok) is very fast growing, medium to the large dioecious tree to $40 \mathrm{~m}$ high under Euphorbiaceae family. In Malaysia, it is known as kayu labuh or garung. Sesendok wood color is creamy-white, the wood is coarse and floatable. Sesendok wood can be used for matches, boxes, crates, current furniture or furniture components, moulding, veneer potentials etc. Sesendok is very light, soaks less humidity, easy to burn; it produces very little ash. So, this plant is very desirable for bio-energy properties research work (Orwa, Mutua, Kindt, Jamnadass, \& Anthony, 2009). 
Proximate Analysis is a partitioning of compounds in a feed into some categories based on the chemical properties of the compounds. The categories are: moisture, ash, crude protein, crude lipid, crude fiber, volatile matter, fixedcarbon, ash and nitrogen-free extracts (digestible carbohydrates). It is a technique what separates and identifies categories of compounds of biomass. This type of analysis of solid fuels allows a prediction to be made as to how the fuel will behave in furnace. It is a very popular analysis to separate the products into different groups such as Moisture Content ( MC ) - absorbed moisture by wood, Ash Content ( AC ) - the inorganic residue remaining after combustion, Volatile Matter (VM ) - consisting of gases \& vapor and Fixed Carbon ( FC ) - the nonvolatile fraction of coal (Dekker, 1998). Calorific Value (CV) is measured by computerized bomb calorimeter by what whole biomass combustion turns into heat (energy) form (Oduor \& Githiomi, 2013).

\section{Materials AND Methods}

\section{Sample Collection}

Freshly chopped small wood pieces of sentang \& sesendok plants collected from Bio-energy Laboratory of Forest Research Institute Malaysia (FRIM).

\section{Testing Methodology}

Determination of Moisture Content, Volatile Matter, Ash Content, Fixed Carbon by Proximate Analysis For both wood samples, the determination of energy properties was similar. The procedures followed are from British Standards BS: 3631 of 1973 (Oduor \& Githiomi, 2013). $0.50 \mathrm{~g}$ of the wood sample placed in 'MX50 Moisture Analyzer' and MC was measured.

To measure VM, adjusted the A-130 Bench-top Furnace (Neycraft Vulcan) furnace temperature at $900^{\circ} \mathrm{C}$ and let it heat until the temperature reached at $900^{\circ} \mathrm{C} .1 .00 \mathrm{~g}$ of the wood sample was placed in a crucible, then it was placed in the furnace. The furnace door was shut and furnace chimney was closed with a lid to make it air-tight. After heating 7 minutes, crucibles were taken out, let them cool down and then measured the sample mass (without crucible). Calculated the VM was written as:

$$
\text { Ash content }=\frac{\text { Final weight of the residue }(g)}{\text { Original weight of the sample }(g)} \times 100
$$

To measure AC, adjusted the furnace temperature at $815^{\circ} \mathrm{C}$ and let it heat until the temperature reached at $815^{\circ} \mathrm{C}$. $1.00 \mathrm{~g}$ of the wood sample placed in the crucible and then it was placed in the furnace. The furnace door closed; let it heat 3 hours and furnace chimney kept opened for air-passing. After 3 hours, the test sample turned into ashes, then the crucible was taken out, let them cool down and then measured the sample mass (without crucible). Calculated the AC was written as:

$$
\text { Volatile matter }=\frac{\text { Weight of Oven dry sample }(g)-\text { residue }}{\text { Original weight }} \times 100
$$

To determine the fixed carbon, Moisture Content (MC), Volatile Matter (VM) and Ash Content (AC) were summed up and then subtracted from 100. The balance is the fixed carbon content.

$$
\text { Fixed Carbon }(F C)=100-(M C+V M+A C)
$$

\section{Determination of Calorific Value}

To determine CV of the wood sample, AC 500 Bomb Calorimeter and a computer connected with Calorimeter was used. At first, let the computer and calorimeter turned on for an hour to dry the combustion chamber and oxygen valve kept opened. Then $1 \mathrm{~g}$ of the sample was measured, logged on the computer to write down sample name. An "Analytical Balance" was used to measure samples. Then the sample was placed inside calorimeter, supplied some oxygen with oxygen pump until the gas pressure made 'fuss' sound. 2 Littre distilled water was placed in the chamber to maintain the temperature that surrounded the Bessel and the sample was inside the Bessel. Then calorimeter top part was covered and connected with the power. Let the machine powered ' $\mathrm{ON}^{\prime}$, started equilibrating and analyzing for 3-7 minutes. After completion of analyzing, the energy amount was on the screen of the computer and Calorific Value was measured.

\section{Determination of Bulk Density}

To measure Bulk Density, the volume and mass of the wood sample was measured and then calculated Density written as:

$$
\text { Bulk Density }=\frac{\text { Mass }}{\text { Volume }}
$$


For both Sentang and Sesendok species, 9 samples for all experiments were taken and then average values were measured to get the highest accuracy in this research.

\section{ResUlt AND Discussion}

The energy properties of Sentang and Sesendok are shown in Table- 1 and Density of samples shown in Table-2. In Table-1, both of the samples have quite high Moisture Content (\%) more than typical range $5 \%-10 \%$ as they were freshly collected chopped samples. High MC replaces combustible matter and decreases the heat content of wood what causes heat loss, radiation heat transfer and evaporation. So, to get higher efficiency, the MC would be reduced by drying process such as sun-drying is the cheapest (Dekker, 1998).

Table 1: Energy Properties of Wood Sample

\begin{tabular}{|l|c|c|c|c|c|}
\hline Wood Sample & $\begin{array}{c}\text { Moisture } \\
\text { Content (\%) }\end{array}$ & $\begin{array}{c}\text { Volatile } \\
\text { Matter (\%) }\end{array}$ & $\begin{array}{c}\text { Ash } \\
\text { Content (\%) }\end{array}$ & $\begin{array}{c}\text { Fixed } \\
\text { Carbon (\%) }\end{array}$ & $\begin{array}{c}\text { Calorific Value } \\
\mathrm{MJ} / \mathrm{kg})\end{array}$ \\
\hline Sentang (Azadirachta excelsa) & 14.83 & 88.55 & 0.34 & 11.09 & 16.84 \\
\hline Sesendok (Endospermum malaccense) & 13.23 & 90.08 & 0.23 & 9.67 & 16.95 \\
\hline
\end{tabular}

According to Table-1, Volatile Matter (\%) for both plants is extremely high that means they contain very high amount of methane, hydrocarbons, hydrogen and other combustible gasses. The more VM, the more flame length will be. Besides, it is great for easier ignition as well. This VM is much higher than typical VM range. Furthermore, Table- 1 showed that sentang contains AC $0.34 \%$ and for sesendok is $0.23 \%$ that is significantly low amount. This result proved that both plants contain very negligible inorganic materials. Besides, high ash content causes fouling deposits, pollution and damage to the refractory at high temperature, shows an erosive effect on burner tips and gives rise to high- temperature corrosion and high cost. Usually, ash content is counted as the impurity, combustion inefficiency and burning incapacity. As in this research, AC is very low, so it would state that both species will provide very pure and efficient combustion bio-energy (Green Gas Emission Reduction from Industry in Asia and the Pacific, 2006).

Fixed Carbon is the major heat generator during burning. It is a solid fuel left in the furnace after VM is distilled off, consists mostly of carbon and gives a rough estimation of the heating value. In this research, FC is high enough, for sentang is $11.09 \%$ and for sesendok is $9.67 \%$. So their heating values are well enough for efficient combustion. If MC reduced, FC would be much higher and give very ideal heating value (Green Gas Emission Reduction from Industry in Asia and the Pacific, 2006).

Calorific Value is the measurement of heat or energy produced. In this research, Net Calorific Value (NCV) was measured and any fuel should be compared based on the NCV. Table-2 showed that CV for sentang and sesendok was respectively $16.84 \mathrm{MJ} / \mathrm{kg}$ and $16.95 \mathrm{MJ} / \mathrm{kg}$ what extremely high amount of energy (Dekker, 1998).

For qualitative calculations and assessing ignition qualities, Bulk Density was calculated in this study. The fixed volume was $800 \mathrm{~cm}^{3}$ and mass was measured. The average bulk density of the wood samples is shown below in Table-2.

Table2: Bulk Density of Wood Sample

\begin{tabular}{|l|c|c|c|}
\hline Wood Sample & Mass $(\mathrm{g})$ & Volume $\left(\mathrm{cm}^{3}\right)$ & Density $\left(\mathrm{kg} / \mathrm{m}^{3}\right)$ \\
\hline Sentang (Azadirachta excelsa) & 122.50 & 800 & 152.5 \\
\hline Sesendok (Endospermum malaccense) & 115.14 & 800 & 143.92 \\
\hline
\end{tabular}

\section{CONCLUSION}

Sentang and Sesendok showed a very high percentage of Volatile Matter, Calorific Value, Fixed Carbon and very low Ash Content. That means both of these species provide fuel-wood with lengthy flammability with the high ignition, significant amount of net bio-energy, great heat generation during burning and very little pollution. So, it is clearly demonstrated that sentang and sesendok are environmentally friendly ideal fuel-wood. Before proximate analysis, the wood sample should go through drying process to reduce moisture content and increase the efficiency. Further research on charcoal of both wood species is recommended. As these plants have high density, they will give high quality of charcoal as well.

The purpose of this research was to analyze bio-energy properties of sentang and sesendok and the result proved successful analyses bio-energy properties. As both plants are native for Malaysia and grow faster, they should be afforested with large scale as the source of bio-energy production to meet up daily basis energy demand in Malaysia. 


\section{ACKNOWLEDGEMENTS}

This work supported by the Bio-energy Laboratory of Production Department of Forest Research Institute Malaysia (FRIM)

\section{REFERENCES}

Abdullah, K. (2005). Renewable energy conversion and utilization in ASEAN countries. Elsevier, Energy(30), 119-128.

Dekker, M. (1998). Thermal Data for Natural and Synthetic Fuels. Austria: International Energy Agency.

Green Gas Emission Reduction from the Industry in Asia and the Pacific (2006). Thermal Equipment: Fuel and Combustion. United Nations Environment Program (UNEP).

Mustapa, T., Wahab, R., \& Choon, L. S. (2009). Abrasive Resistance of Sentang, Rubberwood \& Kempas.

Oduor, N. M., \& Githiomi, J. K. (2013). Fuel-wood energy properties of Prosopis juliflora and Prosopis pallida grown in Baringo District, Kenya. African Journal of Agricultural Research, 8 (21), 2476-2481.

Orwa, C., Mutua, A., Kindt, R., Jamnadass, R., \& Anthony, S. (2009). Agroforestree Database: a tree reference and selection guide version 4.0.

Potential Contribution of Bioenergy to the World's Future Energy. (2007). IEA Bioenergy. 